\title{
Influence of lairage on blood composition of pig and on the development of PSE pork
}

\author{
MARKKU HONKAVAARA \\ Finnish Meat Research Centre, Box 56, \\ SF-13101 Hämeenlinna, Finland
}

\begin{abstract}
The purpose of this study was to investigate the effect of lairage temperature, humidity and time on blood composition and on the development of PSE meat $\left(\mathrm{pH}_{1} \leq 5.8\right)$.

The present study suggested that holding temperature and time had a major influence on porcine stress and meat quality, whereas, lairage humidity had a minor effect on these traits. The higher was lairage temperature the higher carcass temperature $(\mathrm{P}<0.001)$ and log creatine kinase $(\mathrm{CK})$ value $(\mathrm{P}<0.05)$ at slaughter. Prolonged holding time increased muscle glycogen content $(\mathrm{P}<0.01)$ and muscle $\mathrm{pH}_{1}$ value $(\mathrm{P}<0.05)$ but decreased muscle lactate content in pigs slaughtered on transport day.

In summary, the results suggested that the optimum lairage temperature, humidity and time were respectively $15-18^{\circ} \mathrm{C}, 59-65 \%$ and $3-5 \mathrm{~h}$. These resulted in a low muscle lactate content and PSE frequency, whereas muscle glycogen level was high and $\mathrm{pH}_{1}$ in longissimus dorsi (LD) muscle was in the range of 5.9-6.4 which was acceptable for commercial use.
\end{abstract}

Index words: abattoir, lairage, blood composition, creatine kinase, PSE meat

\section{Introduction}

During lairage, pigs are exposed to a strange and fluctuating environment which might be stressful for them. Therefore, meat quality could be improved by minimizing these fluctuations and by proper handling of animals.

Pigs held in fluctuating temperatures (21$32^{\circ} \mathrm{C}$ ) or in conditions of $37^{\circ} \mathrm{C}$ and $100 \%$ relative humidity $(\mathrm{RH})$ yielded carcasses with a more rapid postmortem (p.m.) glycolytic rate than did pigs reared at a constant $27^{\circ} \mathrm{C}$ in a moderate $38-42 \% \mathrm{RH}$ (CASSENS et al., 1975). At the abattoir, even a moderate and short physical stress influenced plasma lactate, glucose and $\mathrm{pH}$ values (KolczaK and Kraeling, 1986; LANNEK, 1976; van der Wal, et al., 1985).

DzAPo et al. (1981) found that the combined effect of blood CK value and rectal temperature accounted for meat quality defects. Moreover, blood CK activity was significant- 
ly correlated with muscle $\mathrm{pH}$ and U.S.D.A marbling score (ADDIs et al., 1974). Furthermore, a high carcass temperature was closely related to a rapid $\mathrm{pH}$ fall and the onset of rigor which developed PSE meat (SyBESMA and van LOGTESTIJN, 1966; WOLTERSDORF and Troeger, 1987).

Earlier papers (HonkavaARA, 1988 and 1989) considered the effect of porcine stress on blood composition and early p.m. meat quality in pigs of different halothane genotypes, and the influence of selection phase, fasting and transport on porcine stress and on the occurrence of PSE. The purpose of this study was to evaluate the effect of lairage temperature, humidity and time on blood composition and on the development of PSE meat.

\section{Material and methods}

\section{Treatment during lairage}

This study was conducted for nine months from September 1985 to May 1986 by collecting $11-12$ pigs per month. The collection of test animals and their treatment programme are described earlier (HonkavaAra, 1988). Thus six, six and ten treatments were carried out at the abattoir in Nurmo, Forssa and Salo, respectively. Each treatment consisted of four to eight pigs from one producer. Consequently, 28, 24 and 50 pigs were slaughtered at the abattoir in Nurmo, Forssa and Salo, respectively.

During unloading, blood drops from the ear vein of test pigs were collected on filter paper test cards (HonkavaAra, 1988). During lairage, the test animals were held in one box, separated from the rest of pigs. Finally they were slaughtered with the other animals of the same producer.

The temperature and humidity of lairage were measured with a portable hygrometer (Humicap HMI 31, Vaisala, Finland). Lairage duration was the time ( $\mathrm{min}$ ) elapsed between unloading and stunning.

\section{Evaluation of porcine stress and meat quality}

Methods used for the evaluation of porcine stress and meat quality are described earlier (HonkavaAra, 1988).

\section{Variables}

The following 16 "lairage variables" were collected: external temperature (ET), duration of lairage (DL), temperature of lairage (TL), humidity of lairage (HL), fast duration (FD), carcass temperature 0 min postmortem (p.m., $\mathrm{CT}_{0}$ ), blood creatine kinase (CK) activity during unloading (CKU), CK activity at exsanguination (CKE), serum glucose (SG), serum glycerol (SGL), serum lactate (SL), serum $\mathrm{pH}(\mathrm{SpH})$, muscle glycogen 0 min p.m. $\left(\mathrm{MG}_{0}\right)$, muscle lactate 0 min p.m. $\left(\mathrm{ML}_{0}\right), \mathrm{pH}$ in $M$. longissimus dorsi $45 \mathrm{~min}$ p.m. $\left(\mathrm{pH}_{1}\right)$, carcass hot weight $(\mathrm{CW})$. Moreover, it was calculated the $\mathrm{CK}$ change $(100 \times(\mathrm{CKE}-\mathrm{CKU}) /$ $\mathrm{CKU}$ ) during lairage. The CKU and CKE values were $\log _{10}$ transformed.

\section{Statistical analyses}

Conventional statistical methods were used to calculate means, standard deviations and standard error of the means (SEM). The relations between the measured "lairage variables" and porcine stress and meat quality were analysed by simple regression. Moreover, to estimate the influence of lairage on blood CK activity and carcass temperature, a stepwise linear regression analysis was performed (statistical program PATO for microcomputers, Mikrovuo, Finland).

The regression model (1) included the dependent variable $Y_{i}(i=1-3)$, the 16 independent variables $X_{j}(j=1-16, j \neq i)$ and the standardized regression coefficients $\mathrm{Bj}$ $(j=1-16, j \neq i)$.

$\mathrm{Y}_{\mathrm{i}}=\mathrm{B}_{1} \mathrm{X}_{1}+\mathrm{B}_{2} \mathrm{X}_{2}+\mathrm{B}_{3} \mathrm{X}_{3}+\ldots+\mathrm{B}_{16} \mathrm{X}_{16}$

Prediction equations (2) were developed 
using stepwise regression analysis (HONKAVAARA, 1989).

$$
\begin{array}{r}
Y_{i}=B_{0}+B_{1} X_{1}+B_{2} X_{2}+\ldots+B_{n} X_{n} \\
(i=1-3, n=3-5)
\end{array}
$$

\section{Results}

\section{Prediction of porcine stress}

Table ! shows the combined effects of studied variables on blood $\mathrm{CK}$ activity and carcass temperature during lairage. Thus the coefficient of determination $\left(\mathrm{R}^{2} \times 100\right)$ of the prediction equations were for the $\mathrm{CK}$ change, $\mathrm{CK}$ at exsanguination and carcass temperature $87.0 \%, 80.5 \%$ and $71.8 \%$, respectively. The combined effects of the independent variables of the prediction equations are discussed below.

\section{Lairage temperature}

In general, temperature of lairage, TL was positively related to external temperature, ET $\left(\mathrm{TL}=15.844+0.548 \mathrm{ET}, \mathrm{R}^{2} 100=20 \%\right.$, $\mathrm{p}<0.001)$. Thus, a $1^{\circ} \mathrm{C}$ increase in external temperature increased lairage temperature by $0.6^{\circ} \mathrm{C}$. In this study, duration of lairage, DL $\left(\mathrm{DL}=1495.69-67.419 \mathrm{TL}, \mathrm{R}^{2} 100=19 \%\right.$, $\mathrm{P}<0.001)$ and fast duration, $\mathrm{FD}(\mathrm{FD}=$ $1583.82-28.224 \mathrm{TL}, \mathrm{R}^{2} 100=7 \%, \mathrm{P}<0.01$ ) were reduced by $67 \mathrm{~min}$ and $28 \mathrm{~min}$ for each degree increase in lairage temperature, respectively. Moreover, carcass hot weight, CW was positively related to lairage temperature $\left(\mathrm{CW}=57.322+1.148 \mathrm{TL}, \mathrm{R}^{2} 100=17 \%, \mathrm{P}<\right.$ $0.001)$ which shows that heavy pigs were slaughtered in warm weather.

Furthermore, a $1^{\circ} \mathrm{C}$ increase in lairage temperature decreased serum lactate, SL by $0.4 \mathrm{mmol} / 1\left(\mathrm{SL}=20.022-0.422 \mathrm{TL}, \mathrm{R}^{2} 100=\right.$ $6 \%, \mathrm{P}<0.02$ ) and increased serum $\mathrm{pH}$, $\mathrm{SpH}$ by $0.2 \mathrm{pH}$ units $(\mathrm{SpH}=7.615+0.024 \mathrm{TL}$, $\mathrm{R}^{2} 100=6 \%, \mathrm{P}<0.02$ ). In addition, increases in external temperature accounted for $60.0 \%$ of the increase in carcass temperature which, on the other hand, accounted for $14.2 \%$ of the elevation in $\mathrm{CK}$ activity during lairage (Table 1). Thus it was concluded that high external and lairage temperature had a detrimental effect on carcass temperature.

The collected data were classified into four groups of nearly the same number of pigs according to the increase in lairage temperature. Table 2 shows the variables that differed significantly between the groups.

At the abattoir, the increase in CK activity was highest at $16^{\circ} \mathrm{C}$, whereas this increase was only $82.0 \%$ without reactors. Heat stress elevated blood CK level both during transport and lairage which resulted in a low increase in $\mathrm{CK}$ activity in the pigs held at $21^{\circ} \mathrm{C}$. In this group, the prolonged heat stress accounted for the smallest muscle glycogen content and the

\begin{tabular}{|c|c|c|}
\hline Prediction equations ${ }^{b}$ & $\mathrm{R}^{2} 100=\%$ & $\mathrm{Df}^{\mathrm{d}}$ \\
\hline \multicolumn{3}{|l|}{ Carcass temperature $=$} \\
\hline $38.609+0.801 \mathrm{ET}-0.178 \mathrm{HL}+0.187 \mathrm{MG}_{0}+0.259 \mathrm{CK}$ change & 71.8 & $4 / 45$ \\
\hline \multicolumn{3}{|l|}{$\mathrm{CK}$ at exsanguination $=$} \\
\hline $194.36+0.514 \mathrm{CKU}-0.092 \mathrm{SL}+0.756 \mathrm{CK}$ change & 80.5 & $3 / 87$ \\
\hline \multicolumn{3}{|l|}{ CK change $e=$} \\
\hline$-1000.33+0.139 \mathrm{CT}_{0}-0.677 \mathrm{CKU}+1.016 \mathrm{CKE}+0.15 \mathrm{SL}-0.151 \mathrm{MG}_{0}$ & 87.0 & $5 / 44$ \\
\hline
\end{tabular}

Table 1. The best stepwise regression models ${ }^{a}$ for predicting porcine stress during lairage.

Regression models have significant $\mathrm{F}$-values $(\mathrm{P}<0.002)$.

b Abbreviations given in text.

- Coefficient of determination $\times 100$.

a Degrees of freedom.

- CK change $(\%)=100 \times \frac{\text { CK at exsanguination }- \text { CK during unloading }}{\text { CK during unloading }}$ 
lowest incidence of PSE. Actually, carcasses of these animals had the slowest $\mathrm{pH}$ fall in the LD muscle (Table 2). On the other hand, the occurrence of PSE was highest at $16^{\circ} \mathrm{C}$, but it decreased to $8.3 \%$ without reactors. The high PSE frequency at $12^{\circ} \mathrm{C}$ might result from the stressful treatment when pigs were woken up after overnight holding and were driven to stunning.

\section{Lairage humidity}

Humidity of lairage, HL was positively related to external temperature, ET ( $\mathrm{HL}=$ $\left.51.945+2.907 \mathrm{ET}, \mathrm{R}^{2} 100=12 \%, \mathrm{P}<0.002\right)$. Thus, a $1{ }^{\circ} \mathrm{C}$ increase in external temperature increased lairage humidity by $2.9 \% \mathrm{RH}$. Furthermore, muscle glycogen content, $\mathrm{MG}_{0}$ was decreased by $0.22 \mu \mathrm{mol} / \mathrm{g}$ for each per cent $\mathrm{RH}$ increase in lairage humidity $\left(\mathrm{MG}_{0}=\right.$ $41.099-0.222 \mathrm{HL}, \mathrm{R}^{2} 100=5 \%, \mathrm{P}<0.03$ ). However, carcass temperature was poorly described by lairage humidity, as indicated by a low partial $\mathrm{R}^{2} 100$ of $4.8 \%$ (Table 1 ).

The collected data were classified into four groups of nearly the same number of pigs ac-

Table 2. Effect of lairage temperature on blood composition and carcass traits.

\begin{tabular}{|c|c|c|c|c|c|}
\hline \multirow[t]{2}{*}{ Variable } & \multicolumn{4}{|c|}{ Lairage temperature, ${ }^{\circ} \mathrm{C}$} & \multirow[t]{2}{*}{ SEM } \\
\hline & 13 & 16 & 18 & 21 & \\
\hline Lairage time, $\mathrm{h}$ & $13.9^{=}$ & $4.4^{b}$ & $4.3^{b}$ & $2.5^{\mathrm{b}}$ & 0.75 \\
\hline Fasting time, $\mathrm{h}$ & $21.8^{a}$ & $17.7^{\mathrm{b}}$ & $17.9^{b}$ & $18.5^{b}$ & 0.52 \\
\hline CK changed, $\%$ & +89.0 & +103.0 & +75.9 & +61.7 & 21.9 \\
\hline Serum glucose, $\mathrm{mmol} / \mathrm{l}$ & $6.7^{\mathrm{a}}$ & 5.0 & 6.1 & $4.4^{b}$ & 0.05 \\
\hline SErum lactate, & $15.5^{\mathrm{a}}$ & $11.1^{\mathrm{b}}$ & 13.3 & $12.2^{b}$ & 0.06 \\
\hline Serum pH & 7.9 & $8.0^{2}$ & 7.9 & $8.3^{b}$ & 0.03 \\
\hline Carcass temperature, ${ }^{\circ} \mathrm{C}$ & $38.9^{a}$ & $38.1^{\mathrm{b}}$ & $38.8^{\text {ac }}$ & $39.6^{c}$ & 0.13 \\
\hline Carcass hot weight, $\mathrm{kg}$ & $69.4^{a}$ & $76.5^{b}$ & $79.5^{b}$ & $79.6^{b}$ & 0.79 \\
\hline $\mathrm{pH}_{1} \leq 5.8$, PSE, $\%$ & 20.8 & 21.4 & 15.8 & 13.3 & - \\
\hline $5.8<\mathrm{pH}_{1} \leq 6.4$ & 66.7 & 46.4 & 47.4 & 26.7 & - \\
\hline $6.4<\mathrm{pH}_{1}$ & 12.5 & 32.2 & 36.8 & 60.0 & - \\
\hline Reactors, $\%$ & 0 & 14.3 & 3.2 & 0 & - \\
\hline Number of pigs & 24 & 28 & 31 & 15 & - \\
\hline
\end{tabular}

a.b.c Means within a row with different superscripts are significantly different $(\mathrm{P}<0.05)$.

d CK change as in table 1 .

Table 3. Effect of lairage humidity on blood composition and carcass traits.

\begin{tabular}{|c|c|c|c|c|c|}
\hline \multirow[t]{2}{*}{ Variable } & \multicolumn{4}{|c|}{ Lairage humidity, $\% \mathrm{RH}$} & \multirow[t]{2}{*}{ SEM } \\
\hline & 38 & 49 & 59 & 70 & \\
\hline CK change ${ }^{a}, \%$ & +33.1 & +149.5 & +89.5 & +62.3 & 21.9 \\
\hline Serum glycerol, mmol/l & 0.54 & $0.43^{b}$ & 0.76 & 0.54 & 0.003 \\
\hline Carcass temperature, ${ }^{\circ} \mathrm{C}$ & $39.1^{\mathrm{b}}$ & 38.8 & $38.2^{c}$ & $38.3 \mathrm{~s}$ & 0.13 \\
\hline Glycogen of LD, $\mu \mathrm{mol} / \mathrm{g}$ & $33.3^{b}$ & 29.0 & $25.3^{c}$ & $30.2^{\mathrm{b}}$ & 0.20 \\
\hline Lactate of LD, n & 44.4 & $50.0^{5}$ & 45.6 & 40.0 & 0.11 \\
\hline $\mathrm{pH}_{1} \leq 5.8$, PSE, $\%$ & 10.5 & 20.8 & 29.0 & 4.2 & - \\
\hline $5.8<\mathrm{pH}_{1} \leq 6.4$, & 42.1 & 54.2 & 45.2 & 58.3 & - \\
\hline $6.4<\mathrm{pH}_{1}$ & 47.4 & 25.0 & 25.8 & 37.5 & - \\
\hline Reactors, \% & 0 & 0 & 18.8 & 0 & - \\
\hline Number of pigs & 19 & 24 & 32 & 24 & - \\
\hline
\end{tabular}

a CK change as in table 1 .

$b, c$ Means within a row with different superscripts are significantly different $(P<0.05)$. 
cording to the increase in lairage humidity. Table 3 shows the variables that differed significantly between the groups. Thus, differences between the groups were not significant for holding and fasting time. Whereas the occurrence of reactors accounted for the high CK values and the highest frequency of PSE in the group of $59 \% \mathrm{RH}$. Without reactors, the incidence of PSE decreased from $29.0 \%$ to $15.4 \%$. Moreover, the group of the highest humidity of $70 \% \mathrm{RH}$ had the lowest CK values during unloading $(\mathrm{P}<0.05)$ and at exsanguination $(\mathrm{P}>0.05)$. While the pigs of the lowest humidity of $38 \% \mathrm{RH}$ had the slowest $\mathrm{pH}$ fall in the LD muscle 45 min p.m., however, these animals had the highest carcass temperature at slaughter.

\section{Lairage time}

In practice, pigs are slaughtered either on the transport day or after overnight holding. In order to compare the effect of lairage time on porcine stress and meat quality the material was divided into the two groups shown in
Table 4. Thus the pigs of the first group, holding time of $2.4 \pm 0.9 \mathrm{~h}$, were fed either in the afternoon and were transported in the next morning, or were fed in the morning and were transported in the middle of the day, in any case they were slaughtered on the transport day. Whereas the pigs of the second group, holding time of $19.0 \pm 2.0 \mathrm{~h}$, were fed at noon of the transport day, and were held overnight at the abattoir before slaughtering. Consequently the difference in fasting time was significant $(\mathrm{P}<0.001)$ between the two groups. In addition, pigs of the short and long holding times were slaughtered, respectively, in the afternoon and in the morning which accounted for the difference in lairage temperature.

In general, serum lactate level, SL was positively related to the duration of lairage, $\mathrm{DL}\left(\mathrm{SL}=11.963+0.003 \mathrm{DL}, \mathrm{R}^{2} 100=8 \%\right.$, $\mathrm{P}<0.005)$. Thus a $60 \mathrm{~min}$ increase in holding time increased serum lactate by $0.18 \mathrm{mmol} / \mathrm{l}$. Nevertheless muscle $\mathrm{pH}_{1}$ was negatively correlated $(\mathrm{P}<0.01)$ with the lairage times of $0.5 \mathrm{~h}$ to $22 \mathrm{~h}$, there were differences in this

Table 4. Effect of lairage time on blood composition and carcass traits.

\begin{tabular}{|c|c|c|c|c|}
\hline \multirow[t]{2}{*}{ Variable } & \multicolumn{2}{|c|}{ Slaughtering } & \multirow{2}{*}{$\begin{array}{l}\text { Sign. } \\
\text { level }^{\text {a }}\end{array}$} & \multirow[t]{2}{*}{ SEM } \\
\hline & $\begin{array}{l}\text { On trans- } \\
\text { port day }\end{array}$ & $\begin{array}{l}\text { After over- } \\
\text { night lairage }\end{array}$ & & \\
\hline Fasting time, $\quad$ h & 16.7 & 24.8 & $* * *$ & 0.52 \\
\hline Lairage temperature, ${ }^{\circ} \mathrm{C}$ & 17.1 & 14.4 & $* * *$ & 0.28 \\
\hline Lairage humidity, $\quad \%$ & 55.1 & 55.3 & ns & 1.18 \\
\hline Log CK during unloading, U/I & 3.5 & 3.3 & ns & 0.35 \\
\hline Log $\mathrm{CK}$ at exsanguination, $\mathrm{U} / 1$ & 3.5 & 3.6 & ns & 0.36 \\
\hline Serum glucose, $\mathrm{mmol} / \mathrm{l}$ & 5.0 & 6.7 & $* *$ & 0.05 \\
\hline Serum glycerol, $\quad "$ & 0.65 & 0.54 & ns & 0.003 \\
\hline Serum lactate, & 12.2 & 15.6 & $* *$ & 0.06 \\
\hline Serum pH & 8.0 & 8.0 & ns & 0.03 \\
\hline Carcass temperature, ${ }^{\circ} \mathrm{C}$ & 38.4 & 39.3 & $* *$ & 0.13 \\
\hline Glycogen of LD, $\mu \mathrm{mol} / \mathrm{g}$ & 30.2 & 22.8 & $* *$ & 0.20 \\
\hline Lactate of LD, " & 44.4 & 47.8 & ns & 0.13 \\
\hline Carcass hot weight, kg & 78.2 & 70.7 & $* * *$ & 0.79 \\
\hline $\mathrm{pH}_{1} \leq 5.8$, PSE, $\%$ & 14.9 & 25.0 & - & - \\
\hline $5.8<\mathrm{pH}_{1} \leq 6.4$, & 44.6 & 67.9 & - & - \\
\hline $6.4<\mathrm{pH}_{1}$ & 40.5 & 7.1 & - & - \\
\hline Reactors, \% & 6.8 & 3.6 & - & - \\
\hline Number of pigs & 74 & 28 & - & - \\
\hline
\end{tabular}

a Significance level: $\mathrm{ns}=$ not significant, $\mathrm{P}<0.01^{* *}, \mathrm{P}<0.001 * * *$. 
relation between the short and long holding times. Actually, in pigs slaughtered on the transport day, a $60 \mathrm{~min}$ prolongation of lairage time increased muscle $\mathrm{pH}_{1}$ value by $0.10 \mathrm{pH}$ units $\left(\mathrm{pH}_{1}=6.042+0.002 \mathrm{DL}, \mathrm{R}^{2}\right.$ $100=6 \%, \mathrm{P}<0.05$ ). Whereas a $60 \mathrm{~min}$ prolongation of holding time decreased muscle $\mathrm{pH}_{1}$ value by $0.05 \mathrm{pH}$ units in the pigs slaughtered after overnight lairage $\left(\mathrm{pH}_{1}=\right.$ $\left.7.019-0.001 \mathrm{DL}, \mathrm{R}^{2} 100=11 \%, \mathrm{P}=0.08\right)$.

The difference in $\mathrm{pH}_{1}$ values between the pig groups results from decreased muscle lactate content $(\mathrm{P}<0.05)$ during holding times of 0.5 to $5.0 \mathrm{~h}$, and from increased muscle lactate level $(\mathrm{P}<0.01)$ during lairage times of 16 to $22 \mathrm{~h}$. Moreover, the pigs slaughtered on the transport day had smaller serum glucose $(\mathrm{P}<0.01)$ and lactate content $(\mathrm{P}<0.01)$, lower carcass temperature $(\mathrm{P}<0.01)$ and higher muscle glycogen content $(\mathrm{P}<0.01)$ than did those slaughtered after overnight holding. In addition, the latter group had lower carcass hot weight $(\mathrm{P}<0.001)$ and higher occurrence of PSE than the former group (Table 4).

The combined effects of fast time, lairage temperature and carcass hot weight on studied variables were evaluated by stepwise regression analysis (HonkavaAra 1989). Thus, serum lactate was influenced positively but mus- cle glycogen negatively by fasting time (partial $R^{2} 100=17.6$ and $8.4 \%$, respectively). On the other hand, lairage temperature contributed only $5.2 \%$ (partial $\mathrm{R}^{2} 100$ ) of the variation in muscle $\mathrm{pH}_{1}$, whereas carcass hot weight was not a contributing component in the analysis.

\section{The change in CK activity at the abattoir}

There were no significant differences in CK activities during unloading or at exsanguination between the three abattoirs. Generally, the change in $\mathrm{CK}$ activity from unloading $(\mathrm{CKU})$ to stunning $(\mathrm{CKE})$ was positively related to the $\mathrm{CK}$ values at exsanguination (CK change $=12.228+0.012 \mathrm{CKE}, \mathrm{R}^{2} 100=44 \%$, $\mathrm{P}<0.001)$, humidity of lairage, $\mathrm{HL}$ (CK change $=-60.254+1.752 \mathrm{HL}, \mathrm{R}^{2} 100=4 \%$, $\mathrm{P}=0.054)$ and carcass temperature, $\mathrm{CT}_{0}$ $\left(\mathrm{CT}_{0}=38.324+0.002 \mathrm{CK}\right.$ change, $\mathrm{R}^{2} 100=$ $19 \%, \mathrm{P}<0.01)$. Thus a $1000 \mathrm{U} / \mathrm{l}$ increase in CK activity at slaughter and $10 \%$ units increase in lairage humidity elevated $\mathrm{CK}$ change by $12.2 \%$ and $17.5 \%$, respectively. Moreover, dublication of CK activity at the abattoir increased carcass temperature by $0.2^{\circ} \mathrm{C}$. Furthermore, the most contributing variables of $\mathrm{CK}$ change were $\mathrm{CK}$ at exsanguination

Table 5. Effect of the change in creatine kinase activity at the abattoir on blood composition and carcass traits.

\begin{tabular}{|c|c|c|c|c|}
\hline \multirow[t]{2}{*}{ Variable } & \multicolumn{3}{|c|}{ CK changea $\%$} & \multirow[t]{2}{*}{ SEM } \\
\hline & -51 & +21 & +266 & \\
\hline Lairage humidity, $\quad \%$ & $51.8^{\mathrm{b}}$ & 56.2 & $58.3^{\mathrm{c}}$ & 1.18 \\
\hline Log CK at exsanguination, $\mathrm{U} / 1$ & $3.1^{\mathrm{b}}$ & $3.6^{\mathrm{c}}$ & $3.9^{\mathrm{d}}$ & 0.36 \\
\hline Serum glucose, $\quad \mathrm{mmol} / \mathrm{l}$ & $6.7^{\mathrm{b}}$ & $5.0^{c}$ & 5.0 & 0.05 \\
\hline Serum pH & $7.9^{b}$ & $8.1^{\mathrm{c}}$ & 8.0 & 0.03 \\
\hline Carcass temperature, ${ }^{\circ} \mathrm{C}$ & $37.7^{b}$ & $38.6^{c}$ & $39.0^{\mathrm{c}}$ & 0.13 \\
\hline Decrease in muscle glycogen 45 min p.m., $\%$ & 18.4 & 16.3 & 15.6 & 7.49 \\
\hline Increase in muscle lactate $45 \mathrm{~min}$ p.m., $\%$ & 57.9 & 32.6 & 46.2 & 5.29 \\
\hline $\mathrm{pH}_{1} \leq 5.8$, PSE, $\%$ & 19.4 & 15.2 & 18.5 & - \\
\hline $5.8<\mathrm{pH}_{1} \leq 6.4, \quad "$ & 45.1 & 51.5 & 55.6 & - \\
\hline $6.4<\mathrm{pH}_{1}$ & 35.5 & 33.3 & 25.9 & - \\
\hline Reactors, \% & 3.2 & 6.1 & 3.7 & - \\
\hline Number of pigs & 31 & 33 & 27 & - \\
\hline
\end{tabular}

a CK change as in table 1. The material is classified into three groups according to the increase in CK change during lairage.

$b, c, d$ Means within a row with different superscripts are significantly different $(P<0.05)$. 
$\left(\mathrm{R}^{2} 100=65.8 \%\right)$ and carcass temperature (14.2\%), whereas CK activity during unloading, muscle glycogen and serum lactate made relatively minor contributions (3.2, 2.1 and $1.7 \%$, respectively).

The collected data were classified into three groups of nearly the same number of pigs according to the increase in CK activity during lairage. Consequently, the $\mathrm{CK}$ change ranged from -82 to $23 \%$, from -18 to $78 \%$ and from 84 to $969 \%$ in the first, second and third group, respectively. The means of these ranges are shown in Table 5 that lists the variables which differed significantly between the groups.

Thus, the pigs with a decrease of $51 \%$ in CK activity at the abattoir had the lowest CK activity at exsanguination $(\mathrm{P}<0.01)$ and carcass temperature $(\mathrm{P}<0.01)$. Moreover, these animals had a higher serum glucose level $(\mathrm{P}<0.01)$ and a lower serum $\mathrm{pH}$ value $(\mathrm{P}<0.05)$ than those with a moderate increase $(21 \%)$ in CK activity (Table 5). Nevertheless, CK change had no significant correlation with serum glucose, serum $\mathrm{pH}$, muscle glycogen content ( 0 and 45 min p.m.), muscle lactate level ( 0 and 45 min p.m.) or muscle $\mathrm{pH}_{1}$ value. However, the pigs with a decrease in CK activity had the highest occurrence of PSE due to the most prominent p.m. glycogen breakdown and lactate formation.

\section{Discussion}

The results showed that the occurrence of halothane positive pigs had a great effect on the studied traits. Since reactors are practically absent from commercially slaughtered pigs they are not reported here in detail.

This study suggested that the optimum lairage temperature was $15-18^{\circ} \mathrm{C}$ which was lower than that $\left(20-23^{\circ} \mathrm{C}\right)$ presented by WeBSTER (1983) to maintain homeothermy with optimal feed conversion efficiency. Combined effect of heat and transport stress caused elevated body temperatures which should be lowered before slaughter, otherwise, according to Sybesma and van Logtestiun
(1966) the high carcass temperature could have a prominent effect on the development of PSE. On the other hand, the effect of holding temperature should be evaluated with other factors as lairage time. Thus, it was found that muscle $\mathrm{pH}_{1}$ correlated positively $(\mathrm{P}<0.05)$ with holding temperature, which was supported by our unpublished results from $\mathrm{pH}_{1}$ measurement in 22709 pigs.

The influence of lairage humidity on the studied variables was not as significant as that of temperature. However, it was found a negative relation $(\mathrm{P}<0.05)$ between humidity and muscle glycogen content.

Lairage temperature and humidity are factors which are difficult and expensive to change in practice. Consequently, it is easier to control holding time than temperature and humidity. In general, the longer lairage time the higher serum lactate level and lower muscle $\mathrm{pH}_{1}$. Augustini and Fischer (1981) found that overnight holding increased PSE frequency slightly, and according to Moss (1981) blood CK at slaughter was higher after overnight than $2 \mathrm{~h}$ lairage. Moreover, FISCHER et al. (1986) concluded that extended fasting period with abattoir stress did not provide any useful way of alleviating the PSE problem. These findings clearly showed the importance of proper pig handling for minimizing porcine stress at the abattoir.

In summary, the results suggested that the optimum lairage temperature, humidity and time were respectively $15-18^{\circ} \mathrm{C}, 59-65 \%$ and $3-5 \mathrm{~h}$. These resulted in a low muscle lactate level and a low PSE frequency, whereas muscle glycogen content was high and $\mathrm{pH}$ in the LD muscle $45 \mathrm{~min}$ p.m. was in the range of 5.9-6.4 which was acceptable for commercial use.

Acknowledgements. The author wishes to thank abattoir personnel of Itikka Lihabotnia and LSO Food for co-operation. Thanks are extended to the Central Association of Artificial Insemination Societies and to the Finnish Animal Breeding Association for genotype determination. Thanks are also given to Mrs. Kirsti Rantanen for laboratory analysis. This investigation was supported by the Finnish Academy. 


\section{References}

Addis, P.B., Nelson, D.A., MA, R.T-I. \& Burroughs, J.R. 1974. Blood enzymes in relation to porcine muscle properties. J. Anim. Sci. 38: 279-286.

Augustini, C. \& Fischer, K. 1981. Behandlung der Schlachtschweine und Fleischbeschaffenheit - eine Felduntersuchung. Fleischwirtsch. 61: 775-785.

Cassens, R.G., Marple, D.N. \& Eikelenboom, G. 1975. Animal physiology and meat quality. Adv. Food Res. 21: $71-155$.

Dzapo, V., Finger, K.W. \& Lodde, H. 1981. Prognostischer Wert von erweiterungsobjektivierenden Hilfsparametern des Halothan-Tests (CK, Herzfrequenz und Rektaltemperatur) im Hinblick auf Fleischhelligkeit beim Schwein. Züchtungskunde 52: 51-59.

Fischer, K., Augustini, C. \& McCormick, R. 1986. Einfluss der Nüchterungsdauer vor dem Schlachten auf die Fleischbeschaffenheit beim Schwein. Fleischwirtsch. 66: 1659-1665.

Honkavaara, M. 1988. Influence of porcine stress on blood composition and early postmortem meat quality in pigs of different halothane genotypes. Meat Sci. 24: $21-29$.

,- 1989 . Influence of selection phase, fasting and transport on porcine stress and on the development of PSE pork. J. Agric. Sci. Finl. 61 (3): 415-423.

Kolczak, T. \& Kraeling, R.R. 1986. Susceptibility to stress, postmortem muscle metabolism and meat

\section{SELOSTUS}

\section{Teurastamon navettaolosuhteiden vaikutus sianveren koostumukseen ja PSE-lihan muodostumiseen}

\section{Markku Honkavaara \\ Lihateollisuuden Tutkimuskeskus, PL 56, 13101 Hämeenlinna}

Työssä selvitettiin teurastamonavetan lämpötilan, kosteuden ja sikojen lepoajan vaikutus veren koostumukseen ja PSE-lihan muodostumiseen.

Navetan lämpötilalla ja lepoajalla oli merkittảvä vaikutus sikojen stressaantumiseen ja lihan laatuun, sen sijaan kosteuden merkitys oli edellisiä vähäisempi. Mitaa lämpimämpaaả navetassa oli sitä korkeampi ruholämpötila $(\mathrm{P}<0.001)$ ja veren kreatiinikinaasiaktiivisuus $(\mathrm{P}<0.05)$. Teurastettaessa siat kuljetuspäivänä lepo- quality of pigs after modification of the fluid volume of the vascular and extravascular spaces. J. Anim. Sci. 62: $646-659$.

LANNEK, N. 1976. Pale, soft, exudative pork and the porcine stress syndrome. Sv. Vet. tidn. 28: 3-8.

Moss, B.W. 1981. The development of a blood profile for stress assessment. In The Welfare of Pigs, (Sybesma, W., Ed.), Martinus Nijhoff, The Hague, Curr. Topics Vet. Med. Anim. Sci. 11: 112-125.

Sybesma, W. \& Logtestijn, J.G. van 1966. Preslaughter temperature and its effect on postmortem metabolism in the pig. Proc. 12th Eur. Meet. of Meat Res. Workers, Sandefjord, paper E13, 11 pp.

WAL, P.G. van der, Engel, B., Essen, G. van \& Hulshof, H.G. 1985. Changes in blood acid-base characteristics, haemoglobin and lactate concentrations due to increasing moderate stress in pigs. I.V.O. - Report B-271, 19 pp.

Webster, A.J.F. 1983. Nutrition and the thermal environment. In Nutritional Physiology of Farm Animals, (Rook, J.A.F. \& Thomas, P.C., Eds.), Longman, 639-669.

Woltersdorf, W. \& Troeger, K. 1987. Schlachttechnik zur Verringerung des PSE-Anteils beim Schwein. Fleischwirtsch. 67: 724-730.

Ms received July 4, 1988 ajan pidentäminen kohotti lihan glykogeenipitoisuutta $(\mathrm{P}<0.01)$ ja $\mathrm{pH}_{1}$-arvoa $(\mathrm{P}<0.05)$, mutta alensi lihan maitohappotasoa $(\mathrm{P}<0.05)$. Tulosten mukaan navetoinnin optimiolosuhteet olivat: lămpötila $15-18^{\circ} \mathrm{C}$, kosteus $59-65 \%$ ja lepoaika $3-5$ h. Näissä olosuhteissa lihan maitohappopitoisuus ja PSE-\% olivat alhaiset, lihan glykogeenitaso oli korkea ja $\mathrm{pH}_{1}$-arvo oli alueella 5.9-6.4, minkä ansiosta liha oli moitteeton jatkojalostukseen. 